\title{
HYPERVOLEMIC ANEMIA IN CIRRHOSIS
}

\author{
By JEANNE C. BATEMAN, HAROLD M. SHORR, AND TORBJORN ELGVIN \\ (From the Department of Medicine, New York University College of Medicine, and the Third \\ Medical Division of Bellevue Hospital, New York City)
}

(Received for publication August 9, 1948)

Anemia is usually considered to exist when there is a reduction of hemoglobin, red blood cells or both, per unit volume of blood. This concept is valid in most types of anemia. There is an apparent tendency on the part of the body to compensate for a reduction in circulating red cell mass by an increase in plasma with resultant more or less normal blood volume for the individual (1). We have found this to be true even with the profound reduction of red blood cell mass occurring in cases of aplastic anemia of unknown etiology. There are, however, certain exceptions wherein gross alterations in total blood volume may mask the true hematological state. Reduction in total blood volume in spite of increase in plasma volume has been reported in pernicious anemia during relapse (2-4). Conversely, a significant increase in total blood volume with a relatively greater increase in plasma volume than in circulating red cell mass may, when only routine blood counts are done, suggest a more severe grade of anemia than actually exists. Such cases might be expected to respond poorly to hematinic agents. The following data suggest that the anemia occurring in cirrhosis of the liver is of this character.

\section{METHODS}

Hemoglobin determinations were done by the oxyhemoglobin method on a Klett Summerson photoelectric colorimeter. Normal hemoglobin values for males were considered to be 16 grams per cent, for females 14 grams per cent. The Nesslerization method was employed for plasma protein determinations and readings were made on a Coleman Junior spectrophotometer. Plasma volume was measured by the Evans Blue (T-1824) dye method using a single blood sample as recommended by Gregersen (5). The plasma dye concentration was determined on a Coleman Junior spectrophotometer. The standard curve was made with plasma. Blood for hematocrit determination was drawn from the antecubital vein following release of the tourniquet. In a small series of simultaneous hematocrit determinations on blood drawn in this manner and femoral vein blood there was found to be no essential difference. Heparin was used as an anticoagulant and hematocrit readings were made after 30 minutes of centrifugation at 3000 r.p.m. Gibson (6) using radioactive iron found the body hematocrit to be about ninetenths of the large vessel hematocrit. This suggests that hematocrit determinations done in the usual way may be too high. Total blood volume was calculated from plasma volume and hematocrit according to the formula:

$$
\frac{\text { Plasma vol. in cc. }}{100-\text { hematocrit }} \times 100=\text { Total blood volume }
$$

Results of total blood volume determinations done on four healthy young male adults ranging from 174 to 180 $\mathrm{cm}$. in height were found to be 5,051, 5,277, 5,500 and 5,532 cc. These figures are slightly lower than those of Gibson (7) for normal individuals of this height. The calculated normal values for blood and plasma volumes of the patients studied were derived from the chart prepared by Gibson and Evans (7) using the patient's height as the basis of the calculation. It has been suggested that in the presence of obesity or significant weight loss, height or ideal weight be employed to predict normal plasma volume (8).

The figures for hemoglobin and red blood counts corrected for expected normal blood volumes were derived by the following formula:

Patient's hemoglobin

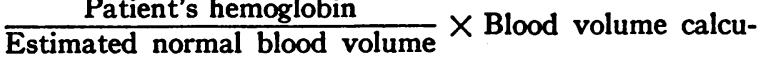
lated by dye hematocrit method = Corrected hemoglobin

$\frac{\text { Patient's red blood count }}{\text { Estimated normal blood volume }} \times$ Blood volume calculated by dye hematocrit method $=$ Corrected red blood count

Bone marrow for study was obtained by sternal puncture done under local anesthesia. The relationship between the sternal marrow findings and the peripheral blood counts is depicted on Figure 1.

\section{MATERIAL}

Seven cases of cirrhosis of the liver from the Third Medical Division of Bellevue Hospital were studied. The hematological observations on these patients were made prior to and during the administration of therapy for cirrhosis as well as for the anemia which the patients exhibited. The studies were terminated by transfer to another hospital (one case), by death (two cases), and arbitrarily when it became obvious that the patient had not responded to hematinic agents in the expected fashion 


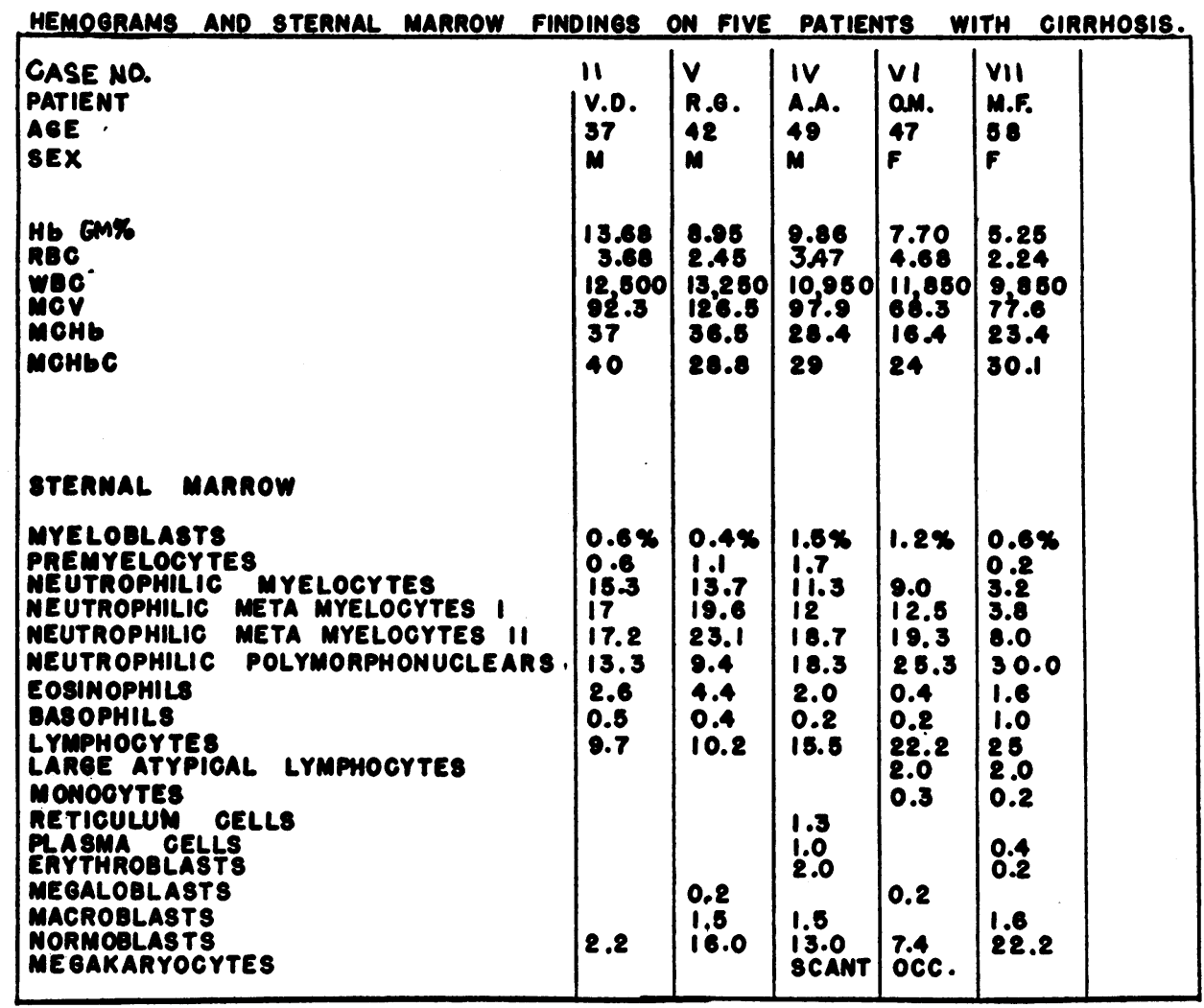

Fig. 1

(three cases). One patient in whom the diagnosis was not clear cut (M. F.) ran an unexpected course.

The data on these cases are summarized in Table I. There are four males and three females ranging from 36 to 58 years of age. All patients but one had histories of excessive alcohol consumption with more than one previous hospital admission for that complaint alone. One male had a history of inadequately treated lues and the female with no history of alcoholism was found to have positive serology on two occasions. The symptoms included weakness of varying duration in all patients and weight loss which was frequently partially masked by ascites formation. Complaints referable to the abdomen were those of vague abdominal discomfort usually promptly followed by the development of swelling. Gastro-intestinal complaints consisted of anorexia in six individuals, bouts of nausea and vomiting in four. Hemorrhagic phenomena had been present at some time in four patients although in the 36 year old male these could be attributed to a concurrent vitamin $C$ deficiency.

Dullness or confusion was present in four patients, milder personality abnormalities in two. Only the nonalcoholic patient showed no signs of mental deterioration. Telangiectasia was present in five cases, hepatomegaly in all, splenomegaly was noticed in only one, jaundice (usually mild or moderate) was present five times, and ascites and edema six times.
Laboratory data are given in the table. Only representative determinations are presented. One patient (M. F.) whose history and physical findings were somewhat atypical was found to have esophageal varices on $\mathrm{X}$-ray as well as biopsy findings compatible with cirrhosis. The diagnosis of cirrhosis was substantiated in two other patients by biopsy studies.

Sternal marrow studies (Figure 1) failed to reveal a megaloblastic bone marrow even in R. G. whose mean corpuscular volume was 126 and who showed a moderately severe grade of anemia. One patient, V. D., who was almost terminal at the time of study manifested a marked depression in the red cell series. No striking abnormalities were noticed, otherwise.

The hematological studies in relationship to blood volume and therapy are presented graphically in Figures 2 to 7 inclusive. No blood volume studies were done on T. M. (Figure 2) but his lack of response to hematinic drugs was characteristic even of patients treated longer and more vigorously. The slight reticulocyte rise observed following institution of therapy was considerably below that which might be expected in an anemia of the degree suggested by his blood counts.

Two patients (V. D. and E. F.) expired shortly after admission to the hospital. It was not possible therefore to observe their response to anti-anemia therapy. However, it will be observed (Figure 3) that the blood counts 
TABLE I

Data on seven cases of cirrhosis of the liver

\begin{tabular}{|c|c|c|c|c|c|c|c|}
\hline Case & I & II & III & IV & $\mathbf{V}$ & VI & VII \\
\hline $\begin{array}{l}\text { Patient } \\
\text { Sex } \\
\text { Age } \\
\text { Ht. } \\
\text { Alcoholism } \\
\text { Lues } \\
\text { Symptoms } \\
\text { Weakness } \\
\text { Weight loss } \\
\text { Abdominal discomfort } \\
\text { Abdominal swelling } \\
\text { Anorexia } \\
\text { Nausea } \\
\text { Vomiting } \\
\text { Bleeding }\end{array}$ & 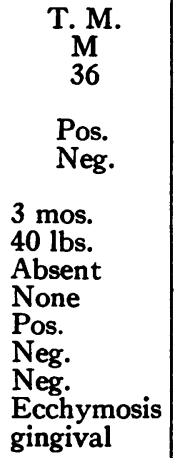 & 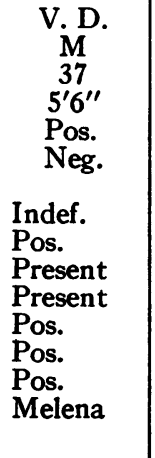 & $\begin{array}{l}\text { E. F. } \\
\text { F } \\
46 \\
5^{\prime} 5^{\prime \prime} \\
\text { Pos. } \\
\text { Neg. } \\
3 \text { mos. } \\
\text { Pos. } \\
\text { Present } \\
1 \text { week } \\
3 \text { mos. } \\
3 \text { mos. } \\
3 \text { mos. } \\
\text { None }\end{array}$ & $\begin{array}{l}\text { A. A. } \\
\text { M } \\
49 \\
5^{\prime} 6^{\prime \prime} \\
\text { Pos. } \\
\text { Pos. } \\
1 \frac{1}{2} \text { mos. } \\
27 \text { lbs. } \\
\text { Present } \\
\text { Present } \\
6 \text { mos. } \\
6 \text { mos. } \\
6 \text { mos. } \\
\text { None }\end{array}$ & 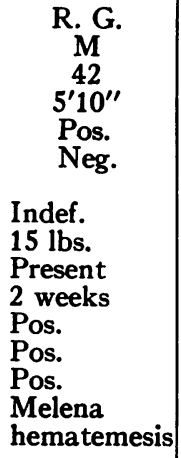 & 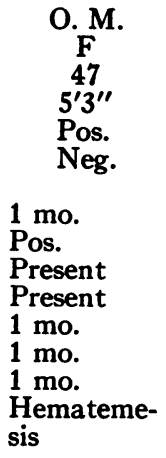 & $\begin{array}{c}\text { M. F. } \\
\text { F } \\
58 \\
4^{\prime} 11^{\prime \prime} \\
\text { Neg. } \\
\text { Pos. } \\
2 \text { mos. } \\
\text { None } \\
\text { Present } \\
2 \text { mos. } \\
\text { None } \\
\text { None } \\
\text { None } \\
\text { None }\end{array}$ \\
\hline $\begin{array}{l}\text { Signs } \\
\text { Confusion } \\
\text { Telangiectasia } \\
\text { Hepatomegaly } \\
\text { Splenomegaly } \\
\text { Jaundice } \\
\text { Ascites } \\
\text { Edema } \\
\text { Laboratory findings } \\
\text { Albuminuria } \\
\text { Urobilinogenuria } \\
\text { Bilirubinuria }\end{array}$ & $\begin{array}{l}\text { None } \\
\text { Present } \\
\text { Present } \\
\text { Absent } \\
\text { None } \\
\text { Minimal } \\
\qquad+\end{array}$ & $\begin{array}{l}\text { Marked } \\
\text { Present } \\
\text { Present } \\
\text { Mod. } \\
\text { Present } \\
\text { Present } \\
\quad+ \\
++ \\
+++\end{array}$ & $\begin{array}{l}\text { Mod. } \\
\text { Present } \\
\text { Present } \\
\text { Slight } \\
\text { Slight } \\
\text { Present } \\
\text { Present } \\
\quad+ \\
1: 40 \\
++++\end{array}$ & $\begin{array}{l}\text { Dullness } \\
\text { Present } \\
\text { Present } \\
\text { Slight } \\
\text { Marked } \\
\text { Present } \\
\qquad \\
+ \\
1: 20 \\
+\end{array}$ & $\begin{array}{l}\text { None } \\
\text { Present } \\
\text { Present } \\
\text { Mild } \\
\text { Slight } \\
\text { None } \\
\qquad \begin{array}{c}+ \\
1: 10 \\
+\end{array}\end{array}$ & $\begin{array}{l}\text { Marked } \\
\text { Absent } \\
\text { Present } \\
\text { Mod. } \\
\text { Marked } \\
\text { Present } \\
+ \\
1: 200 \\
+\end{array}$ & $\begin{array}{l}\text { None } \\
\text { Absent } \\
\text { Present } \\
\text { None } \\
\text { Marked } \\
\text { Mild } \\
\text { Neg. }\end{array}$ \\
\hline $\begin{array}{l}\text { Total plasma prot., gm. \% } \\
\text { A/G ratio } \\
\text { Cephalin flocculation } \\
\text { Thymol turbidity } \\
\text { Alkaline phos. } \\
\text { Cholesterol total } \\
\text { esters } \\
\text { Non-protein nitrogen } \\
\text { Icterus index }\end{array}$ & $\begin{array}{c}7.6 \\
\text { Pos. } \\
3.4 \\
267\end{array}$ & $\begin{array}{c}5.6 \\
23 / 33 \\
\text { Str. pos. } \\
11 \\
6.8 \\
44 \\
8 \\
27 \\
150-240\end{array}$ & $\begin{array}{r}141 \\
37 \\
57 \\
18\end{array}$ & $\begin{array}{c}6.5 \\
2.5 / 4.0 \\
\text { Str. pos. } \\
8.6 \\
5.0 \\
67 \\
49 \\
37 \\
18\end{array}$ & $\begin{array}{c}6.9 \\
3.4 / 3.5 \\
\text { Str. pos. } \\
21.5 \\
9.1 \\
436 \\
321 \\
33 \\
21\end{array}$ & $\begin{array}{c}6.4 \\
3.0 / 3.4 \\
\text { Str. pos. } \\
8.8 \\
283 \\
82 \\
25 \\
32\end{array}$ & $\begin{array}{l}5.6 \\
2.7 / 2.9 \\
\text { Neg. } \\
12.8 \\
252 \\
116 \\
35 \\
4\end{array}$ \\
\hline $\begin{array}{l}\text { Hb. in gm. \% } \\
\mathrm{RBC} \text { in millions } \\
\mathrm{MCV}, \mathrm{cu} . \mu\end{array}$ & $\begin{array}{l}10.1 \\
3.12 \\
115\end{array}$ & $\begin{array}{c}13.6 \\
3.68 \\
93\end{array}$ & $\begin{array}{l}11.7 \\
3.40 \\
103\end{array}$ & $\begin{array}{c}9.8 \\
3.47 \\
98\end{array}$ & $\begin{array}{l}8.9 \\
2.45 \\
126\end{array}$ & $\begin{array}{c}7.7 \\
4.68 \\
68\end{array}$ & $\begin{array}{c}5.2 \\
2.24 \\
77\end{array}$ \\
\hline $\begin{array}{l}\text { Blood volume in cc. } \\
\text { Plasma volume in cc. }\end{array}$ & & $\begin{array}{l}6506 \\
4294\end{array}$ & $\begin{array}{l}5365 \\
3510\end{array}$ & $\begin{array}{l}6147 \\
4064\end{array}$ & $\begin{array}{l}7043 \\
4860\end{array}$ & $\begin{array}{l}5290 \\
3995\end{array}$ & $\begin{array}{l}4425 \\
3720\end{array}$ \\
\hline Esophageal varices & & Suggestive & & & & & Present \\
\hline Liver biopsy & & & & Cirrhosis & Cirrhosis & & Cirrhosis \\
\hline
\end{tabular}

recalculated on the basis of normal blood volumes for individuals of their height (7) suggested that these patients were not actually anemic.

Intraheptol was ineffective and folic acid produced only an insignificant reticulocytosis in A. A. and R. G. (Figures 4 and 5). The hemoglobin and red blood cell values recalculated on the basis of normal blood volumes are again found to be higher than routine blood counts indicated.

Two patients (O. M. and M. F.) had a microcytic hypochromic type of anemia (Figures 6 and 7). Parenteral liver extract which had been given for the patient's liver disease resulted in no alteration in the blood picture of $O$. M. However, a reticulocyte response followed by a rise in hemoglobin (determination made at another hospital following patient's transfer) indicates a favorable response to iron in this case. M. F. likewise showed an improvement in her blood count. She received liver extract and ferrous sulfate simultaneously. It was felt that iron alone would probably have been equally effective.

\section{DISCUSSION}

In a study of 132 patients with hepatic disorder Wintrobe (9) concluded that, except when hemorrhage or a complicating infection was associated with it, anemia occurring in liver disease was 


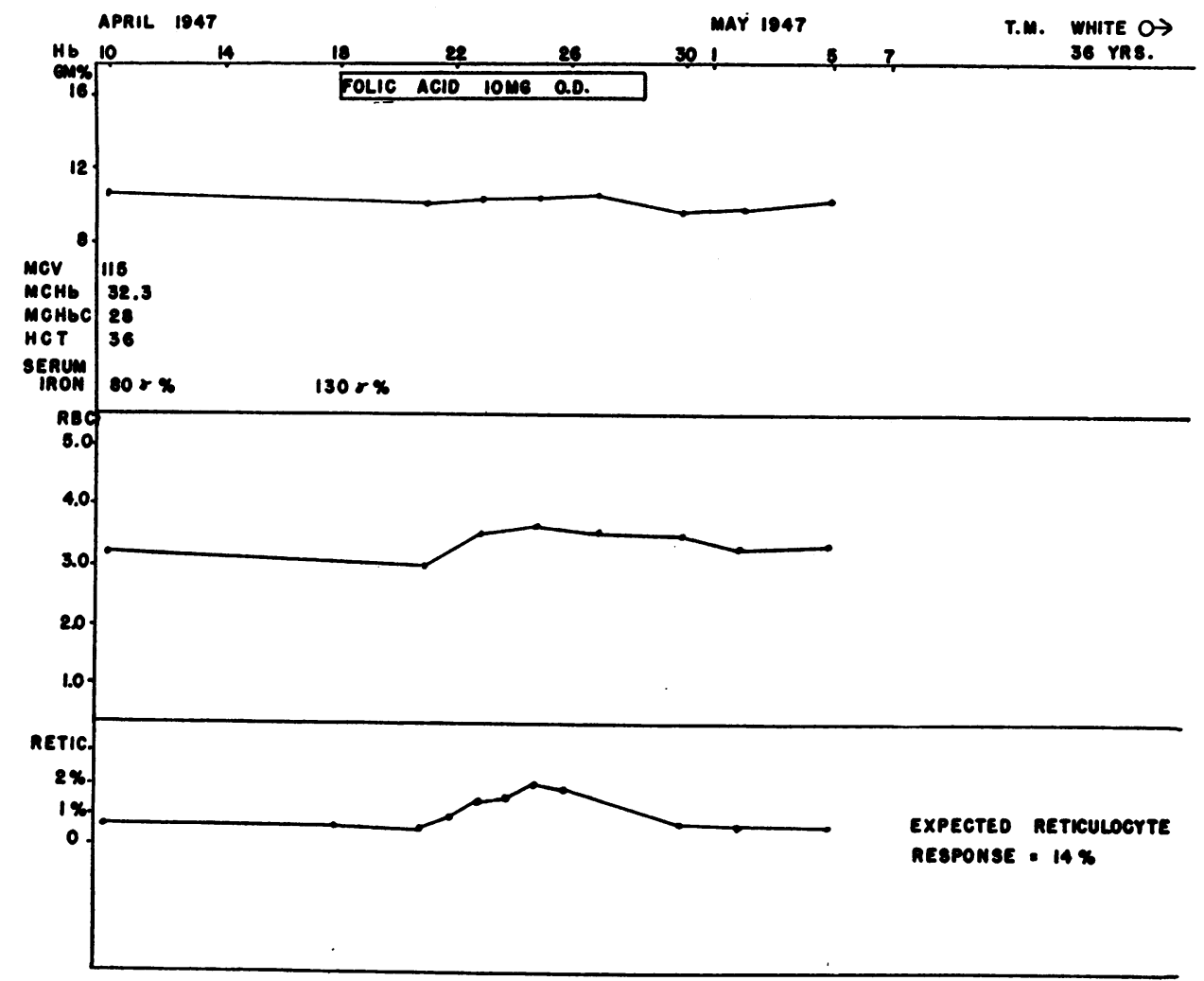

Fig. 2. Folic Acid Therapy in a Case of Cirrhosis with Minimal Hematological Response

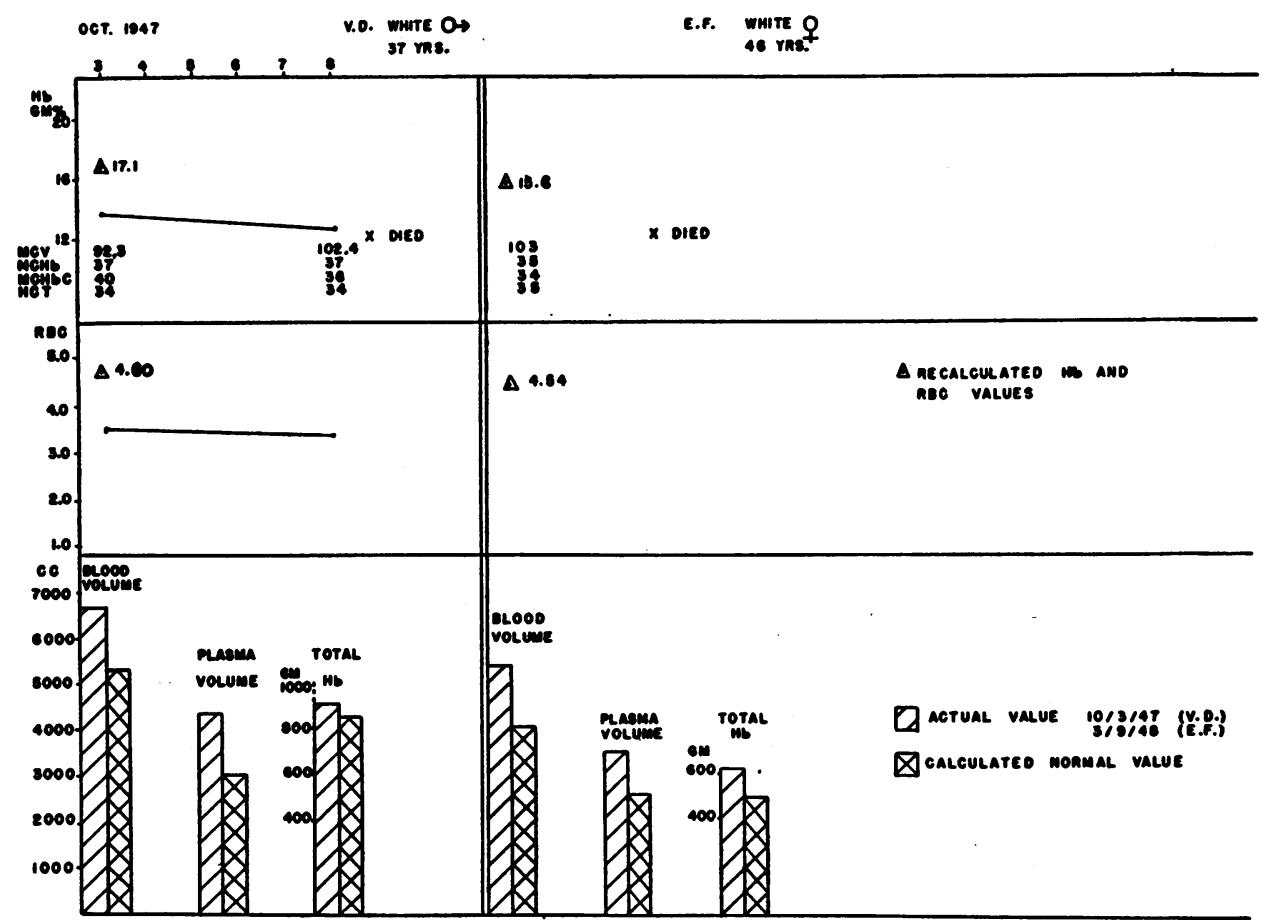

Fig. 3. Actual Blood and Plasma Volumes Compared with the Calculated Expected Normal Values in Two Patients Who Died

Hemoglobin and red blood cell counts recalculated on basis of expected normal blood volumes are shown to be much higher than routine blood counts would indicate. 
normocytic or macrocytic. Furthermore when macrocytic anemia was present it was morphologically similar to that seen in pernicious anemia and like the latter manifested spontaneous remissions and was influenced by intramuscular liver therapy. Goldhamer (10) reported a case of cirrhosis of the liver in which free $\mathrm{HCl}$ was present in the gastric contents and in which the blood picture simulated that seen in pernicious anemia. There was a response to parenteral liver extract but the figures given suggest that it was very slight. Goldhamer concluded that interference with storage of anti-anemic principle was a factor in the production of macrocytic anemia in cirrhosis. Win- trobe and Shumacker (11) obtained a clear-cut response to liver therapy in only one out of four patients. Schiff, Rich and Simon (12) prepared extracts from the livers obtained at post mortem from five patients with chronic liver disease, including two with cirrhosis. The extracts were administered to a suitably controlled group of patients with pernicious anemia in relapse. A characteristic reticulocytosis resulted followed by an increase in hemoglobin and red blood cells and marked clinical improvement. This response was attributed to the presence of anti-anemic principle in the liver extract administered.

Hypochromic macrocytic anemia is an infre-

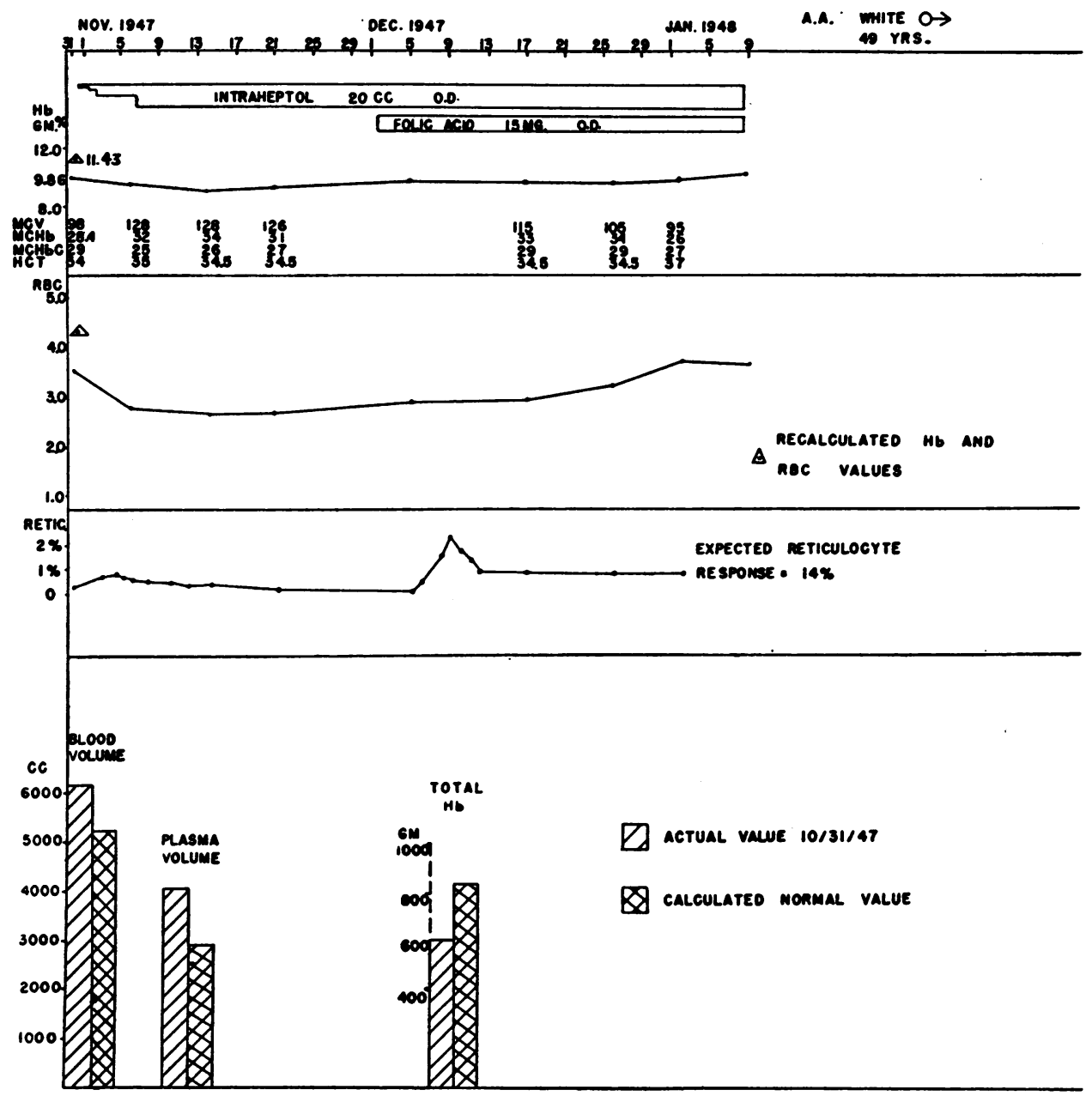

Fig. 4. Hematological and Blood Volume Studies in Patient Who Received Large Doses OF INTRA HEPToL AND Folic ACID

Hemoglobin and red blood cell values recalculated on basis of expected normal blood volume are seen to be higher than those found on routine counts. Hematological response to therapy poor. 


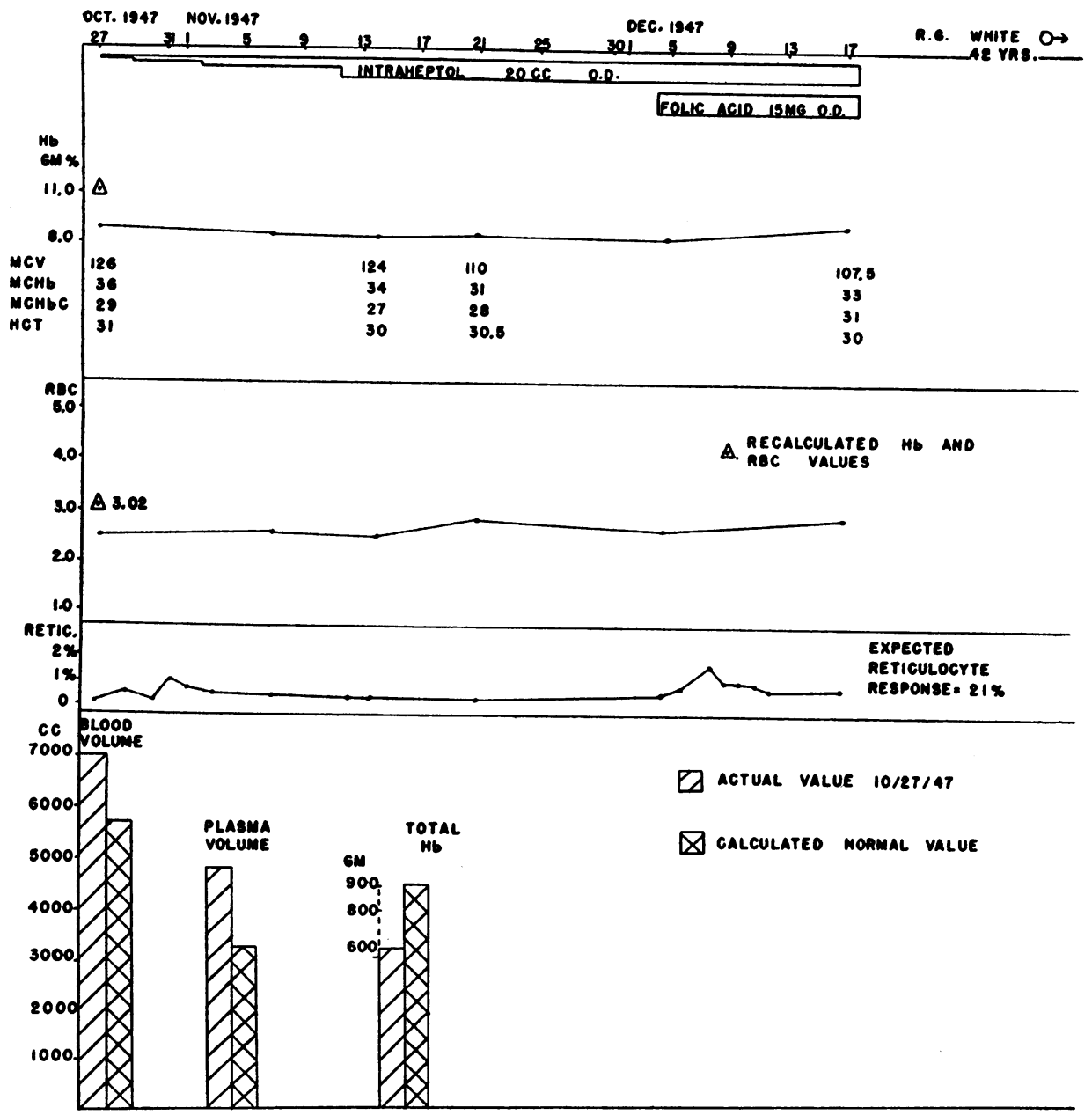

Fig. 5. Prolonged Therapy with Intraheptol Supplemented by Folic Acid with no Appreciable Alteration in Hematological Picture

Recalculated hemoglobin and red blood cell values 11 grams per cent and 3.02 millions respectively.

quent finding. Davis and Brown (13) describe two cases having mean corpuscular volumes of 100 and 101 cubic microns and mean corpuscular hemoglobin concentrations of 23 and 26 per cent respectively. We had previously noticed the occurrence of this type of anemia in some patients with cirrhosis. In this series of cases three patients (T. M., A. A., R. G.) exhibited a persistently macrocytic hypochromic anemia while in one patient (M. F.) a microcytic hypochromic anemia changed to a macrocytic hypochromic anemia during therapy. The latter finding is probably due to a double deficiency involving depleted iron stores as well as a lack of, or inability to utilize, the erythrocyte maturation factor.
Hypervolemia has been reported as occurring in cirrhosis of the liver (14) as well as in acute liver disease (15). Labby (15) has suggested that failure of the acutely inflamed liver to store blood efficiently may partially explain the concomitant rise in circulating red cell mass found in the latter condition.

Intraheptol is considered to have three units of anti-anemic principle per $\mathrm{cc}^{1}{ }^{1}$ and would therefore be expected to have an action similar to that of purified liver extract. An extensive literature has recently appeared on the use of folic acid as an effective agent in the treatment of macrocytic anemia of various types (16-24). While the he-

${ }^{1}$ Personal communication from Dr. Elaine P. Ralli. 
matological response obtained in pernicious anemia may not be as marked as when parenteral liver extract is used, the results with folic acid are impressive. In sprue and other nutritional macrocytic anemias folic acid therapy compares favorably with liver therapy.

Neither intraheptol nor folic acid altered the hematological status of our patients. The small reticulocyte rise following folic acid administration is considered to be not significant.

When, however, the hematological picture is considered in the light of the marked increase in blood volume it becomes apparent that the majority of these patients actually had either no deficiency in total red cell mass and hemoglobin or only a mild one.
Bleeding phenomena as hematemesis, melena, gingival oozing, and ecchymosis were present or reported in the histories of three male patients. Two of these patients (T. M., R. G.) as well as one (A. A.), whose past history was extremely unreliable, showed a mild hypochromia of the red blood cells with a macrocytosis. Two of the women had a hypochromic microcytic anemia. This is not surprising since mild hypochromic anemia secondary to chronic menstrual blood loss is a common finding. The picture is a little complicated in that both of these patients received liver extract as well as ferrous sulfate. It is interesting to note that the blood picture in M. F. assumed a macrocytic character after her hematological response to therapy. In view of the findings in the

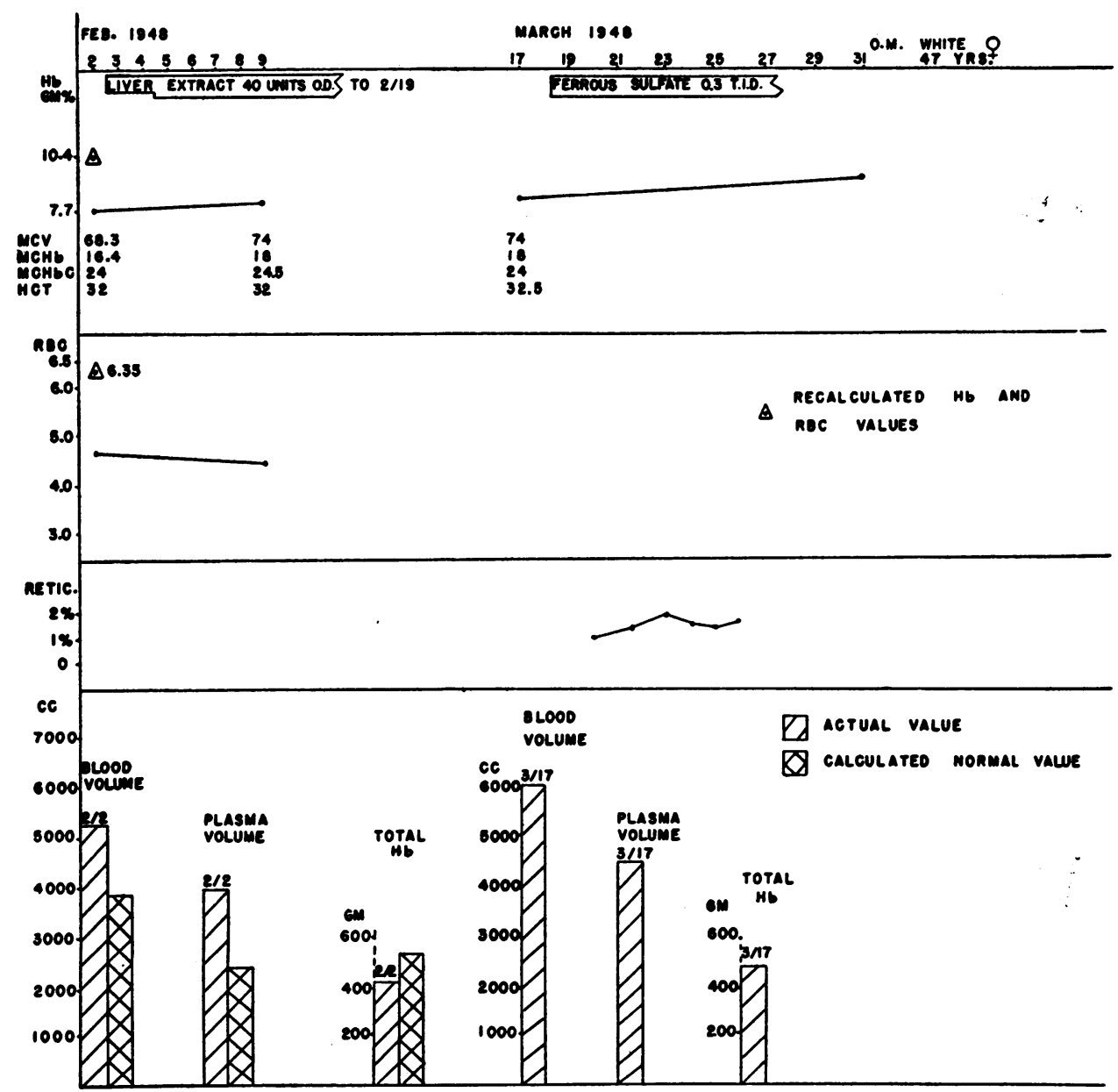

Fig. 6. Hypochromic Microcytic Type of Blood Picture Showing Response to Ferrous Sulfate Therapy

Blood and plasma volume determinations done on two occasions are markedly above calculated normal values. 


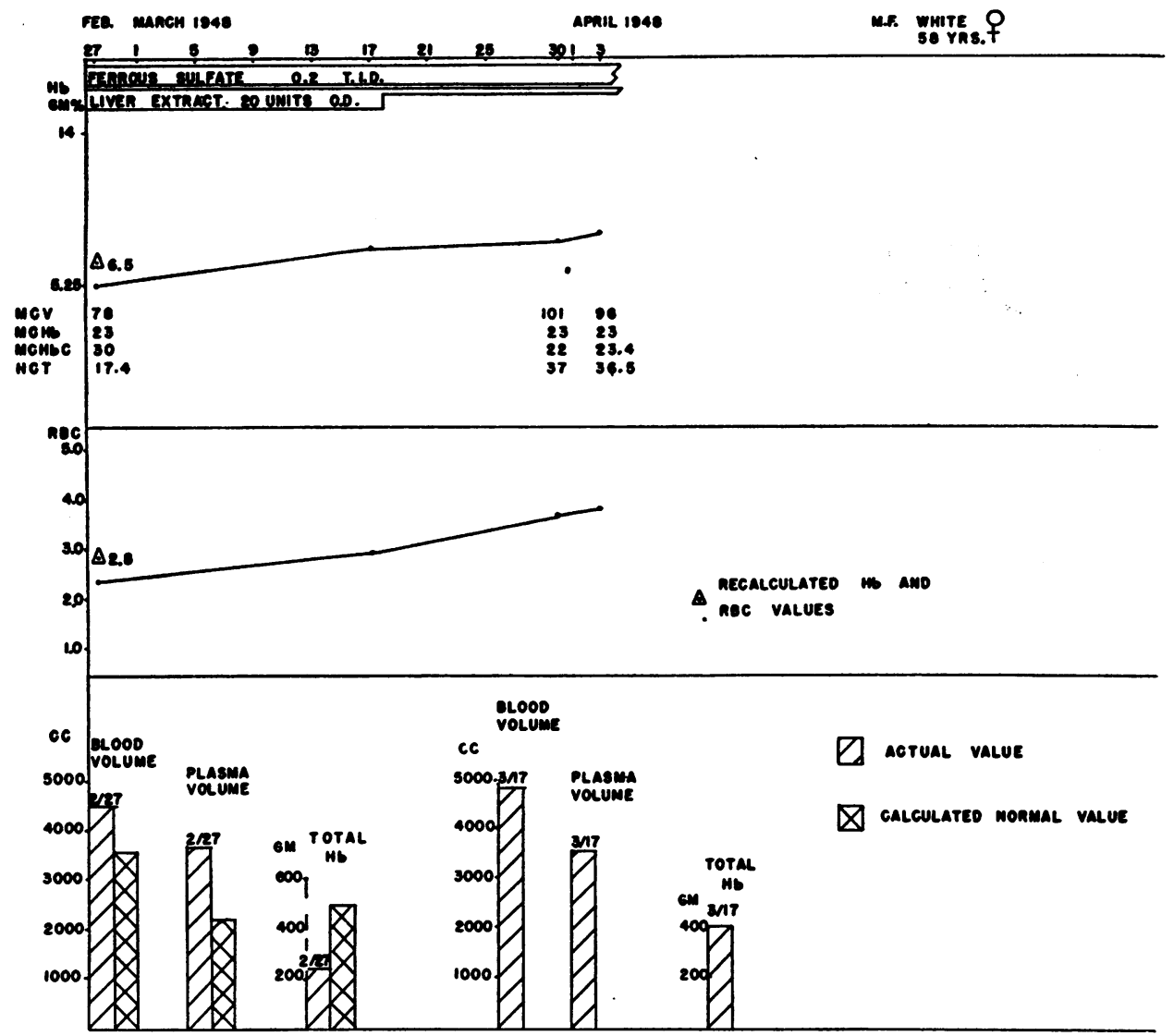

Fig. 7. Hematological Response to Liver and Iron Therapy with Change from Microcytic to Macrocytic Type of Blood Picture

other cases reported it is felt that ferrous sulfate alone would have been as effective in these women as when combined with liver extract.

\section{SUMMARY AND CONCLUSIONS}

1. The marked increase in total blood volume with a relatively greater increase in plasma than in circulating red cell mass occurring in cirrhosis, when only routine hematological studies are made, suggests a more severe degree of anemia than exists.

2. The presence of an almost normal circulating red cell mass may partially explain the poor response to anti-anemic agents in macrocytic anemia associated with cirrhosis.

3. Hypochromic microcytic anemia occurring in chronic liver disease apparently responds to ferrous sulfate therapy in some cases.

\section{BIBLIOGRAPHY}

1. Gibson, J. G., Harris, A. W., and Swigert, V. W., Clinical studies of blood volume; macrocytic and hypochromic anemias due to chronic blood loss, hemolysis and miscellaneous causes, and polycythemia vera. J. Clin. Invest., 1939, 18, 621.

2. De Wesselow, O. L. V., and Bamforth, J., Blood and plasma volumes in pernicious anemia. Lancet, 1928, 1, 1066.

3. Denny, George $P$., Blood volume in pernicious anemia. Arch. Int. Med., 1921, 27, 38.

4. Gibson, John G., 2nd, Clinical studies of the blood volume; changes in blood volume in pernicious anemia in relation to the hematopoietic response to intramuscular liver extract therapy. J. Clin. Invest., 1939, 18, 401.

5. Gregersen, Magnus I., A practical method for the determination of blood volume with the dye T-1824. J. Lab. \& Clin. Med., 1944, 29, 1266.

6. Gibson, J. G., 2nd, Peacock, W. C., Seligman, A. M., and Sack, T., Circulating red cell volume measured simultaneously by the radioactive iron and dye methods. J. Clin. Invest.; 1946, 25, 838. 
7. Gibson, J. G., 2nd, and Evans, Wm. A., Jr., Clinical studies of the blood volume; the relationship of plasma and total blood volume to venous pressure, blood velocity rate, physical measurements, age, and sex in 90 normal humans. J. Clin. Invest., 1937, 16, 317.

8. Perera, George A., The effect of significant weight change on the predicted plasma volume. J. Clin. Invest., 1946, 25, 401.

9. Wintrobe, M. M., The relation of disease of the liver to anemia. Arch. Int. Med., 1936, 57, 289.

10. Goldhamer, S. Milton, Liver extract therapy in cirrhosis of the liver. Arch. Int. Med., 1934, 53, 54.

11. Wintrobe, M. M., and Shumacker, H. S., Jr., Occurrence of macrocytic anemia in association with disorder of the liver. Johns Hopkins Hosp. Bull., 1933, 52, 387.

12. Schiff, L., Rich, M. L., and Simon, S. D., The "Haematopoietic Principle" in the diseased human liver. Am. J. M. Sc., 1938, 196, 313.

13. Davis, L. J., and Brown, Alexander, The erythropoietic activity of choline chloride in megaloblastic anemia. Blood, 1947, 2, 407.

14. Perera, G. A., The plasma volume in Laennec's cirrhosis of the liver. Ann. Int. Med., 1946, 24, 643.

15. Labby, D. H., and Hoagland, C. L., Water storage and movements of body fluids and chlorides during acute liver disease. J. Clin. Invest., 1947, 26, 343.
16. Moore, C. V., Bierbaum, O. S., Welch, A. D., and Wright, L. D., Activity of synthetic Lactobacillus casei factor as antipernicious anemia substance. J. Lab. \& Clin. Med., 1945, 30, 1056.

17. Spies, T. D., Lopez, G. G., Menendez, J. A., Minnich, V., and Koch, M. B., Effect of folic acid in sprue. South. M. J., 1946, 39, 30.

18. Darby, W. J., Jones, E., and Johnson, H. C., Effect of synthetic Lactobacillus casei factor in treatment of sprue. J. A. M. A., 1946, 130, 780.

19. Suarez, Ramon M., Spies, Tom D., and Suarez, Ramon M., Jr., Use of folic acid in sprue. Ann. Int. Med., 1947, 26, 643.

20. Kemp, T. A., Liver and folic acid in the treatment of nutritional macrocytic anemia. Lancet, 1947, 2,350 .

21. Meyer, Leo M., Folic acid in treatment of pernicious anemia. Blood, 1947, 2, 50.

22. Berry, L. J., and Spies, T. D., The present status of folic acid. Blood, 1946, 1, 271.

23. Waldenström, Jan, Successful treatment of liverrefractory anemia with synthetic Lactobacillus casei factor. Blood, 1947, 2, 426.

24. Spies, T. D., Lopez, G. G., Stone, R. E., Milanes, F., Brandenburg, R. O., and Aramburu, T., Further observations on the specificity of the folic acid molecule. Blood, 1948, 3, 121. 